that the main argument of their opponents was that it did not because it could be demonstrated that it could not, a view which I consider erroneous.

R. M. DEELEY.

Melbourse House,

Osmastox Road, Derby.

THE DISCUSSIONS AT THE GEOLOGICAI SOCIETY.

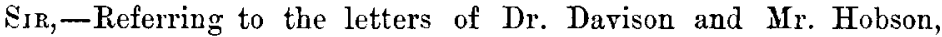
would not the case be fully met, in the circumstance of the author not being present at the reading of his paper, if the Assistant Secretary were to send the author a copy of the abstract containing the discussion with a request that he would return any reply he might wish to malie to be inserted as a postscript in the Quarterly Journal? I have myself been permitted to avail myself of this privilege in the case of my paper on the "Dewlish Elephant Trench" (rol. 1xi, 1905), and can appreciate its sufficiency. If the author is present there is no hardship, for if his cause is a good one he can strengthen it by replying to his critics there and then, and his reply will appear in the Journal. O. Frsher.

April 3, 1909.

\title{
OBITUARY.
}

\section{FREDERICK GEORGE HILTON PRICE, F.S.A., F.G.S.} Borx AUgust 20, 1842.

Died Makch 14, 1909.

We regret to record the death of Mr. Hilton Price, Director of the Society of Antiquaries, who, while distinguished as an archæologist, had also rendered important services to geological science. In 1860, at the age of 18, he entered the banking house of Messrs. Child \& Co., Temple Bar, and eventually became head acting partner. With an intimate knowledge of business, of wide culture, possessed of a fine presence and of genial disposition, he was equally welcome on the council of the Bankers' Institute or on that of a learned society.

To the Geologists' Association in early sears he gave much time and attention, and carried out the duties of treasurer from 1875 to 1881. He joined the Geological Society in 1872, and serred on the Council for a short period in 1878-9. In later years his time, apart from business, was much occupied in archæological pursuits, including Egyptology and numismatics.

In his work upon the Gault Mr. Price was intimately associated with Mr. J. Starkie Gardner, F.G.S., and for many years they subsidized Griffiths, the well-known Folkestone collector, and made rich collections of the very finest Gault fossils. Mr. Gardner's collection was acquired by the British Museum, and Mr. Price's by his friend Mr. Hudleston, of which it still forms an integral part.

To geologists Mr. Price is best known through his detailed researches on the stratigraphy and palæontology of the Gault of Folkestone. He divided the formation into eleren zones, excluding 